\title{
Embryo Rescue in Wide Crosses in Arachis. 3. In vitro Culture of Peg Tips of A. hypogaea Selfs and Interspecific Hybrids ${ }^{1}$
}

\author{
J. P. Moss* and H. T. Stalker ${ }^{2}$
}

\section{ABSTRACT}

Embryo rescue in wide crosses in Arachis has only been achieved from culturing ovules excised from well developed pods, or from immature pods derived from flowers treated with gibberellic acid (GA) and which had embryos large enough to dissect without injury. The objective of this study was to determine whether reproductive tissues could grow in vitro without the need to dissect them from the peg tip and to determine the effects of GA application on flowers at the time of pollination age of peg when cultured, and the presence of the peg meristem on reproductive growth, callus production, and peg elon-

'Paper No. 605 of the Journal Series of the International Crops Research Institute for the Semi-Arid Tropics (ICHISAT), Patancheru, P.O., Andhra Pradesh 502 324, India and Paper No. 10404 of the Journal Series of the North Carolina Agricultural Research Service, Raleigh, NC 27695-7601. Use of trade names does not imply endorsement of the products nor criticisms of ones not mentoned. Research was supported in part by SEA-CR grant no. 83-CRCR-1-1334.

${ }^{2}$ Principal Cytogeneticist, ICRISAT, Patancheru, P.O., Andhra Pradesh 502 324, India and Associate Professor, Department of Crop Science, North Carolina State University, Raleigh, NC 27695. Research was conducted by the senior author while on sabbatical study leave at North Carolina State University. gation in vitro. Pegs elongated in culture only when the peg meristem was not removed. Ovules enlarged and grew out of the surrounding peg tissue in 3.8 to $32.8 \%$ of the cultures. Significantly more ovules grew when the peg meristem was removed $(\mathrm{p}<0.01)$ and when 10 - and 20 - day-old pegs were cultured $(\mathrm{p}<0.05$ ). Overall, the most successful treatment for growth of ovules was treating flowers with GA at pollination and culturing without the peg meristem 10 days after pollination when 25.0 and $32.8 \%$ of all hybrid and selfed ovules, respectively, grew. Embryo growth was observed in an average of 8.4 and $17.6 \%$ of embryo sacs in hybrid and self peg tips, respectively, with several embryos reaching the globular stage after 21 days in vitro. This illustrates the potential for culturing young reproductive tissues of Arachis to recover interspecific hybrids.

Key Words: Groundnut, peanut, gibberellic acid, callus production, ovule growth.

Interspecific hybridization has been of interest in the genus Arachis since Hull and Carver (6) made the first wide hybrids. Arachis species have many desirable traits, including high levels of resistance to diseases, in- 
sects, and nematodes (1). Introgression of germplasm to the cultivated peanut (A. hypogaea L.) has been successful for some species (12), while for other species it has been limited because of genomic incompatibilities, hybrid breakdown, and ploidy level differences $(20,21)$.

Singh et al. (19) and Gardner and Stalker (2) hybridized $A$. hypogaea with amphidiploids of section Arachis. Although many pegs were produced after pollination, most pegs ceased elongation and aborted before reaching the soil. Mallikarjuna and Sastri (10) showed that gibberellic acid-3 (GA) induced pegging in some noncompatible Arachis crosses. In other crosses among Arachis species, Johansen and Smith (7) attributed failure to slow growth and degeneration of the embryo. Further, Halward and Stalker (5) showed that some interspecific hybrid embryos die as early as 6 days after pollination, whereas others remain viable until the pod ripens but do not develop and enlarge. The possibility thus exists to recover embryos by ovule and/or embryo culture from many interspecific crosses.

Early studies on in vitro embryo culture in peanuts concentrated on regenerating embryos of $A$. hypogaea. Martin (11) recovered plants from small ovules, but Sastri et al. (18) could only produce callus using the same media as used in Martin's experiment. Hormone treatments followed by ovule culture have been successful for recovering plants $(9,10)$, but recovery percentages are too low for large-scale production of hybrids. Johnson (8) concluded that in vitro culture of small embryos of peanuts requires a two-step process where ovules are cultured until they become large enough to excise and then culture of the embryo. Peg tips and embryos of the cultivated species have been cultured, showed embryo growth $(14,17)$, or produced viable seeds and plants $(23,24)$.

The objectives of this investigation were to evaluate reproductive growth in cultured peg tips which were excised at different developmental stages and to evaluate the effects of floral application of GA and the presence of peg meristem on reproductive development.

\section{Materials and Methods}

Plants of $A$. hypogaea L., cv. NC 4, were grown in the greenhouse at North Carolina State University, Raleigh during the summer of 1985. The investigation consisted of a 2 (self vs. interspecific hybrid) $x 2$ (presence or absence of GA) x $3(4,10$, or 20-day excision time) $x$ 2 (presence or absence of peg meristem) factorial experiment:

(1) Flowers of NC 4 were either emasculated and pollinated with the tetraploid amphidiploid [A. duranensis Krap. et Greg. nom. nud (coll. K 7988) x A. chacoense Krap. et Greg. nom. nud. (coll. GKP 10602)] or self-pollinated (Table 1). All flowers, whether self- or crosspollinated, were tagged and numbered at the time of pollination to identify individual flowering nodes.

(2) GA treatment was applied by wrapping the base of the flower hypanthium in cotton soaked in an 88-ppm aqueous solution of GA just prior to pollination. Separate plants were used for GA-treated and nontreated nodes to prevent translocation of GA to nontreated plant parts.

(3) Pegs were excised from the plant 4,10, or 20 days after pollination. The 12 treatments are listed in Table 1 . Pegs were sterilized in $600 \mathrm{~mL} 20 \%$ sodium hypochlorite with $3 \mathrm{~mL}$. Tween 80 for $15 \mathrm{~min}$ and then washed three times for 15 min each in sterile distilled water. Peg length was measured and peg tips excised under a dissecting microscope fitted with an ocular micrometer scale.

(4) Peg tips without meristems were excised by cutting tranversely $1 \mathrm{~mm}$ from the tip, which is an effective method for removal of the
Table 1. Numbers of self and hybrid pollinations to generate materials for in vitro culture of peanut peg tips.

\begin{tabular}{|c|c|c|c|c|c|c|}
\hline $\begin{array}{l}\text { Self or } \\
\text { hybrid }\end{array}$ & $G A^{a}$ & $\begin{array}{c}\text { Age } \\
\text { (days) }\end{array}$ & $\frac{\text { Nur }}{\text { Poll. }}$ & $\frac{\text { ber of }}{\text { Cultures }}$ & $\begin{array}{l}\text { \% Cultures/ } \\
\text { pollination }\end{array}$ & $\begin{array}{c}\text { Avg peg } \\
\text { length }(\mathrm{mm})^{b}\end{array}$ \\
\hline $\begin{array}{l}5 \\
S \\
5 \\
5 \\
5 \\
5\end{array}$ & $\begin{array}{l}+ \\
+ \\
+ \\
- \\
- \\
-\end{array}$ & $\begin{array}{r}4 \\
10 \\
20 \\
4 \\
10 \\
20\end{array}$ & $\begin{array}{l}118 \\
153 \\
266 \\
192 \\
143 \\
290\end{array}$ & $\begin{array}{r}103 \\
119 \\
97 \\
162 \\
118 \\
108\end{array}$ & $\begin{array}{l}87.3 \\
77.8 \\
36.5 \\
84.4 \\
82.5 \\
37.2\end{array}$ & $\begin{array}{r}104 \\
298 \\
647 \\
84 \\
280 \\
730\end{array}$ \\
\hline $\begin{array}{l}H \\
H \\
H \\
H \\
H \\
H \\
H\end{array}$ & $\begin{array}{l}+ \\
+ \\
+ \\
- \\
- \\
-\end{array}$ & $\begin{array}{r}4 \\
10 \\
20 \\
4 \\
10 \\
20\end{array}$ & $\begin{array}{l}141 \\
167 \\
387 \\
281 \\
225 \\
495\end{array}$ & $\begin{array}{r}99 \\
99 \\
144 \\
93 \\
53 \\
125\end{array}$ & $\begin{array}{l}70.2 \\
59.3 \\
37.2 \\
33.1 \\
23.6 \\
25.3\end{array}$ & $\begin{array}{r}125 \\
293 \\
595 \\
61 \\
231 \\
670\end{array}$ \\
\hline & & & 2858 & 1320 & & \\
\hline
\end{tabular}

$a_{+}=$gibberellic acid applied, - = no gibberellic acid applied.

bength of peg at time of removal from plant.

peg meristem (15). For practical reasons, peg tips to be cultured with meristems intact were shortened by cutting to a total length of $4 \mathrm{~mm}$.

The 1320 excised peg tips were placed partially in the medium in individual $60 \times 15-\mathrm{mm}$ plastic disposable petri plates sealed with Parafilm and containing $9 \mathrm{~mL}$ medium. Plates were incubated at $27 \mathrm{C}$ in the dark. The medium used, selected on the basis of prior experiments (14), was Murashige and Skoog's (16) major and minor nutrients, with the addition of $100 \mathrm{mg} / \mathrm{L}$ myoinositol, $1 \mathrm{mg} / \mathrm{L}$ nicotinic acid, $10 \mathrm{mg} / \mathrm{L}$ thiamine $\mathrm{HCl}, 1 \mathrm{mg} / \mathrm{L}$ pyroxidine, $2 \mathrm{mg} / \mathrm{L}$ glycine, 0.2 $\mathrm{mg} / \mathrm{L}$ IAA, $0.1 \mathrm{mg} / \mathrm{L}$ kinetin, $125 \mathrm{~g} / \mathrm{L}$ sucrose, and $7 \mathrm{~g} / \mathrm{L}$ agar.

Peg tips were scored 21 days after culturing. Previous experiments (15) had shown a range of responses among cultured peg tips, and cultures were assigned to one of 14 classes (Table 2). For analyses, these were combined into three groups to better define the objectives as follows: ovule growth (classes 1 to 7), callus production (classes 2-4 and $8-12$ ), and peg elongation (classes $5+6+12+13$ ). To eliminate the effects of imbibing water, pegs were only considered to have elongated if they were at least $1 \mathrm{~mm}$ longer after 21 days than at the initiation of the experiment. Two hundred fifty-six peg tips were fixed in FAA (9 parts 70\% EtOH:0.5 parts glacial acetic acid:0.5 parts formalin) for $48 \mathrm{~h}$ and then stored in $70 \% \mathrm{EtOH}$. Tissues were dehydrated, embedded in paraplast, sectioned at $10 \mu \mathrm{m}$ thickness, stained with a safranin-O/fast green/orange-G series, and observed under the microscope. Embryos were scored as having grown when more than 4-celled embryos were observed in 4-day-old peg tips, when more than 8-celled embryos were observed in 10-day-old peg tips, and when globular embryos were observed in 20-day-old peg tips based on the expected normal embryo development (4).

Table 2. Reponse of Arachis peg tips cultured 4, 10, or 20 days after pollination averaged across selfs and hybrids, gibberellic acidtreated and nontreated pegs, and pegs with and without meristems.

\begin{tabular}{|c|c|c|c|c|}
\hline \multirow{2}{*}{$\begin{array}{l}\text { Response } \\
\text { Ovule growth }\end{array}$} & \multicolumn{3}{|c|}{ 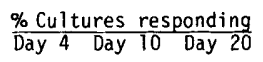 } & $\mathrm{SE} \pm$ \\
\hline & & & & \\
\hline $\begin{array}{l}\text { 1) Basal ovule onty } \\
\text { 2) Basal ovule + peg callus at cut surface } \\
\text { 3) Basal ovule + peg split } \\
\text { 4) Basal ovule + peg callus + split } \\
\text { 5) Basal ovule + peg elongation } \\
\text { 6) Basal ovule + peg elongation + callus } \\
\text { 7) Apical ovule growth }\end{array}$ & $\begin{array}{l}6.3 \\
0.7 \\
1.3 \\
0.0 \\
1.6 \\
1.3 \\
0.2\end{array}$ & $\begin{array}{l}5.5 \\
0.7 \\
5.0 \\
0.5 \\
0.7 \\
0.7 \\
3.3\end{array}$ & $\begin{array}{l}4.5 \\
0.3 \\
4.8 \\
0.3 \\
4.5 \\
0.3 \\
2.1\end{array}$ & $\begin{array}{l}0.8 \\
0.2 \\
0.5 \\
0.1 \\
0.4 \\
0.5 \\
0.5\end{array}$ \\
\hline \multicolumn{5}{|l|}{ Callus growth with no ovule growth } \\
\hline $\begin{array}{l}\text { 8) At cut surface } \\
\text { 9) Callus + peg split } \\
\text { 10) Covering peg } \\
\text { 11) At mid-peg only } \\
\text { 12) Callus + peg elangation }\end{array}$ & $\begin{array}{r}7.2 \\
1.8 \\
2.4 \\
1.7 \\
13.6\end{array}$ & $\begin{array}{r}11.0 \\
2.4 \\
2.1 \\
6.9 \\
12.1\end{array}$ & $\begin{array}{l}4.8 \\
0.6 \\
1.2 \\
3.0 \\
5.1\end{array}$ & $\begin{array}{l}0.7 \\
0.4 \\
0.5 \\
1.0 \\
1.0\end{array}$ \\
\hline \multicolumn{5}{|l|}{ Elongation } \\
\hline 13) Elongate only & 19.5 & 13.6 & 12.7 & 3.8 \\
\hline 14) No response & 42.3 & 35.5 & 55.6 & 1.5 \\
\hline
\end{tabular}

An analysis of variance was performed on the data using the general linear models procedure of the Statistical Analysis System (SAS). Variables were transformed to percentages to create normality of data; covariate analyses on peg length and peg color were performed to test the effects of these variables on responses in culture. 


\section{Results and Discussion}

Many attempts have been made to produce hybrids between $A$. hypogaea and related Arachis species, but the only success has been among species in section Arachis (3) where a number of disease-resistant derivatives have been produced (13). Although hybrid embryos have been rescued from intersectional crosses (18), embryos abort at an early stage of development, are difficult to remove undamaged, and a very low frequency of hybrid recovery has been experienced. Even when ovules are used for culturing, the tissues smaller than $3 \mathrm{~mm}$ long are difficult to excise (9). Peg tip culture has the advantage of rescuing very young hybrids without damage to either the ovule or embryo.

When GA was applied to selfed flowers at the time of pollination, the pegging frequency was approximately the same as for selfed flowers without GA application (Table 1). However, gibberellic acid application to the base of the flower hypanthium at the time of pollination significantly increased the number of pegs produced for interspecific crosses. This agrees with previous results reported by Mallikarjuna and Sastri (10) and Stalker et al. (22). At 4 days the GA-treated pegs were significantly longer than nontreated tissues which may be the result of earlier meristematic initiation caused by GA treatments (Table 1). By 10 days after pollination for both selfs and hybrids, the observed differences in peg lengths between GA-treated and non-treated plants were not significant. At day 20 the pegs not treated with GA were consistently longer than those treated with GA. Covariate analyses to determine the effect of peg length on in vitro culture response showed that peg length was not a significant covariable on ovule growth, callus formation, or peg elongation for in vitro culture. These findings support using GA in interspecific hybridization to enhance peg development. Although GA had no effect on ovule growth in culture, there was an effect on peg elongation. The number of hybrid ovules per pollination which could be cultured was thus greater when treated with GA (Table 1). The present study supports the role of GA in initiating peg meristematic activity in hybrids.

Significant differences were not observed between selfed peg tips of NC 4 and the interspecific hybrids NC $4 \times 4 \times(A$. duranensis $\times A$. chacoense) for reactions in vitro. This is most likely an indication of strong maternal influence on ovule development. Overall, $44.5 \%$ of the peg tips showed no visible response to culture.

An analyses of variance for ovule growth showed significant differences for meristems $(p<0.01$ ), age at culture $(p<0.05)$, and age $x$ meristem interaction $(p<$ 0.05) (Table 3). Ten- and 20-day-old pegs exhibited more growth than 4-day-old tissues, and the meristem had the greatest effect on ovule development in culture. Neither GA nor tissue origin, whether self or hybrid, had significant effects on ovule growth. When the meristem was removed, $19.6 \%$ of all ovules enlarged as compared to only $9.8 \%$ when the meristem was left intact. This effect was most likely due to an inhibition of ovule growth by the meristem. Ovules were observed breaking the peg by splitting or by emerging out of the apical end in pegs from all collection dates, even though 4-day-old tissues were initially very small. Few differences between self and hybrid materials with respect to ovule growth were observed. The percentage of tissues in which ovules grew ranged from $3.8 \%$ for 10 -day-old selfed pegs without GA and with a meristem to $32.8 \%$ for 10-day-old selfed pegs with GA but without a meristem. In six of the 24 treatments, less than $10 \%$ of ovules grew (Table 4). The common factor in these six treatments was the presence of the meristem, although the group included pegs collected at 4,10 , and 20 days from both selfs and hybrids and GA-treated and nontreated plants. Six treatment combinations were also observed with greater than $20 \%$ ovule growth. The meristem had been removed from all six of these combinations; and the group included tissues with and with-

Table 3. Analysis of variance for ovule growth in peanut peg tip cultures for gibberellic acid treatment, selfs or hybrids, peg meristems present or removed, and age of tissues.

\begin{tabular}{lccc}
\hline Source & df & Mean square & $F$ \\
\hline Ovule growth & 14 & .0073 & $5.21^{\star *}$ \\
Gibberellic acid (GA) & 1 & .002 & 0.15 \\
Self or hybrid & 1 & .0009 & 0.63 \\
Meristem & 1 & .0574 & $40.42^{\star *}$ \\
Age at culture (4, 10, 20 days) & 2 & .0068 & $4.81^{\star}$ \\
GA x self or hybrid & 1 & .0048 & 3.38 \\
GA x meristem & 1 & .0013 & 0.94 \\
GA x age & 2 & .0034 & 2.40 \\
Self or hybrid x meristem & 1 & .0008 & 0.53 \\
Self or hybrid x age & 2 & .0025 & 1.72 \\
Age x meristem & 2 & .0064 & $4.48^{*}$ \\
Error & 9 & .0014 & \\
Total & 23 & & \\
\end{tabular}

*,**Indicate significance at 0.05 and 0.01 levels of probability, respectively.

Table 4. Summary of observed responses of peanut peg tips of selfs and hybrids collected on different days, treated or not treated with gibberellic acid and with and without meristems.

\begin{tabular}{|c|c|c|c|c|c|c|c|}
\hline $\mathrm{GA}^{\mathrm{a}}$ & $\begin{array}{l}\text { Self or } \\
\text { hybrid }\end{array}$ & Day & Meristem & $\begin{array}{l}\text { Ovule } \\
\text { growth }\end{array}$ & Callus & $\begin{array}{c}\begin{array}{c}\text { Elonga- } \\
\text { tion }\end{array} \\
\% \\
\end{array}$ & $\begin{array}{l}\text { Embryo } \\
\text { growth }\end{array}$ \\
\hline \multirow[t]{6}{*}{-} & Hybrid & 4 & $\begin{array}{l}\text { Excised } \\
\text { Present }\end{array}$ & $\begin{array}{l}14.6 \\
11.9\end{array}$ & $\begin{array}{l}10.4 \\
38.1\end{array}$ & $\begin{array}{r}0.0 \\
76.2\end{array}$ & $\begin{array}{l}14.7 \\
18.4\end{array}$ \\
\hline & & 10 & $\begin{array}{l}\text { Excised } \\
\text { Present }\end{array}$ & $\begin{array}{l}22.5 \\
13.9\end{array}$ & $\begin{array}{l}22.5 \\
38.9\end{array}$ & $\begin{array}{r}0.0 \\
44.4\end{array}$ & $\begin{array}{l}9.5 \\
0.0\end{array}$ \\
\hline & & 20 & $\begin{array}{l}\text { Excised } \\
\text { Present }\end{array}$ & $\begin{array}{r}23.3 \\
8.7\end{array}$ & $\begin{array}{l}13.3 \\
17.4\end{array}$ & $\begin{array}{r}3.3 \\
30.4\end{array}$ & $\begin{array}{l}14.3 \\
18.2\end{array}$ \\
\hline & Self & 4 & $\begin{array}{l}\text { Excised } \\
\text { Present }\end{array}$ & $\begin{array}{l}14.1 \\
10.3\end{array}$ & $\begin{array}{l}18.8 \\
41.2\end{array}$ & $\begin{array}{r}1.2 \\
75.0\end{array}$ & $\begin{array}{l}16.3 \\
19.7\end{array}$ \\
\hline & & 10 & $\begin{array}{l}\text { Excised } \\
\text { Present }\end{array}$ & $\begin{array}{r}16.3 \\
3.8\end{array}$ & $\begin{array}{l}18.4 \\
39.6\end{array}$ & $\begin{array}{r}0.0 \\
66.0\end{array}$ & $\begin{array}{l}29.6 \\
20.0\end{array}$ \\
\hline & & 20 & $\begin{array}{l}\text { Excised } \\
\text { Present }\end{array}$ & $\begin{array}{l}24.7 \\
16.7\end{array}$ & $\begin{array}{l}3.7 \\
7.1\end{array}$ & $\begin{array}{l}13.0 \\
50.0\end{array}$ & $\begin{array}{r}5.9 \\
15.7\end{array}$ \\
\hline \multirow[t]{7}{*}{+} & Hybrid & 4 & $\begin{array}{l}\text { Excised } \\
\text { Present }\end{array}$ & $\begin{array}{r}10.9 \\
5.1\end{array}$ & $\begin{array}{l}21.7 \\
40.1\end{array}$ & $\begin{array}{r}2.2 \\
62.7\end{array}$ & $\begin{array}{l}8.0 \\
7.9\end{array}$ \\
\hline & & 10 & $\begin{array}{l}\text { Excised } \\
\text { Present }\end{array}$ & $\begin{array}{r}25.0 \\
8.2\end{array}$ & $\begin{array}{l}43.8 \\
54.1\end{array}$ & $\begin{array}{r}0.0 \\
37.7\end{array}$ & $\begin{array}{l}0.0 \\
4.5\end{array}$ \\
\hline & & 20 & $\begin{array}{l}\text { Excised } \\
\text { Present }\end{array}$ & $\begin{array}{l}14.3 \\
10.9\end{array}$ & $\begin{array}{l}21.4 \\
26.1\end{array}$ & $\begin{array}{r}3.6 \\
32.6\end{array}$ & $\begin{array}{l}0.0 \\
4.8\end{array}$ \\
\hline & Self & 4 & $\begin{array}{l}\text { Excised } \\
\text { Present }\end{array}$ & $\begin{array}{r}15.4 \\
8.5\end{array}$ & $\begin{array}{l}11.5 \\
38.3\end{array}$ & $\begin{array}{r}0.0 \\
83.0\end{array}$ & $\begin{array}{l}12.5 \\
18.7\end{array}$ \\
\hline & & 10 & $\begin{array}{l}\text { Excised } \\
\text { Present }\end{array}$ & $\begin{array}{r}32.8 \\
7.1\end{array}$ & $\begin{array}{l}23.0 \\
39.3\end{array}$ & $\begin{array}{r}1.6 \\
69.6\end{array}$ & $\begin{array}{r}5.9 \\
20.0\end{array}$ \\
\hline & & 20 & $\begin{array}{l}\text { Excised } \\
\text { Present }\end{array}$ & $\begin{array}{l}22.0 \\
12.8\end{array}$ & $\begin{array}{r}9.8 \\
25.6\end{array}$ & $\begin{array}{r}2.4 \\
53.9\end{array}$ & $\begin{array}{l}16.7 \\
30.0\end{array}$ \\
\hline & Average & & & 14.7 & 26.0 & 29.5 & 13.0 \\
\hline $\begin{array}{l}\text { SE+ } \\
\text { CV\% }\end{array}$ & & & & $\begin{array}{r}0.8 \\
25.6\end{array}$ & $\begin{array}{r}1.0 \\
17.9\end{array}$ & $\begin{array}{r}1.1 \\
18.2\end{array}$ & \\
\hline
\end{tabular}

$a_{-}=$no gibberellic acid application to flower, $+=$gibberellic acid applied to flower. 
out GA, selfs and hybrids, and pegs collected at either 10 or 20 days. Thus, removal of the peg meristem before culture significantly increased the percentage of growing ovules. However, Pattee et al. (15) reported that the embryo is crushed in rapidly growing selfed ovules in cultured peg tips. The growth is apparently callus proliferation rather than normal reproductive development in ovules. Thus, selection against large ovules, rather than for them, is necessary when attempting to recover viable embryos through culture of peg tips.

Embryo growth was observed in $0-18.4 \%$ of hybrids and 5.9 to $30.0 \%$ of selfs (Table 4). Globular embryos were observed in a small percentage of 4-, 10- and 20day-old peg tips after 21 days in vitro. Application of GA did not appear to suppress embryo growth, while presence of meristem may have a small enhancing influence on embryo development.

Elongation of the peg was evaluated in the cultured tissues because of the possible interactions of peg growth and embryo development. When the peg initiates elongation, the embryo normally stops developing until after soil penetration. The peg then ceases growth and the embryo develops rapidly. In this study, peg elongation was only observed when the peg meristem was not removed. The elongation of the peg was the direct result of activity of the meristem proximal to the basal ovule. Elongation of peg tips in culture was most frequent when 4-day-old tissues were cultured. In addition, more $(\mathrm{p}<0.01)$ selfs elongated than hybrids and significant $(\mathrm{p}<0.01)$ interactions existed between the presence or absence of meristem and age at culture and between self or hybrid. For example, $66.3 \%$ of the selfed pegs with meristem elongated but only $47.3 \%$ of the hybrids with meristem were observed to elongate. GA did not have significant effects on elongation of pegs in culture. While the meristem could have had an inhibitory effect on ovule growth, elongation per se probably had little or no effect on reproductive development. As opposed to earlier experiments by Moss et al. (14), no roots were produced on the peg tissues.

Significant differences among treatments were also observed for callus production (Table 4). Variables which contributed to differences included (a) GA, which enhanced production $(p<0.01)$; (b) type of tissue, with more $(p<0.01)$ callus observed on selfed vs. hybrid tissues; and (c) age of tissue with more callus formed from the younger tissues. Significant $(p<0.01)$ day-bymeristem interactions were observed where $39.6 \%$ of all 4-day-old pegs with meristems produced callus, whereas only $19.1 \%$ of the 20 -day-old pegs with meristems produced callus. Removal of the meristem consistently resulted in less callus growth. As opposed to peg elongation, callus production is an undesirable feature of culture if it interferes with growth of desired tissues. Most of the callus produced was on tissues which did not have ovule growth, which agreed with previously reported results (15). Further experiments are needed to assess the effect of media components on callus production vs. reproductive growth.

Possibly the most important application of peg tip cultures will be to recover very young ovules which would otherwise abort before the embryo is large enough to be excised. The experiments showed that hybrid embryos will continue to grow in cultured peg tips. Overall, embryo growth was observed in $14.5 \%$ of all 4-day hybrid embryo sacs. Though this percentage may vary with different hybrid combinations and may be improved by refinements of media, it indicates that peg tip culture has practical applications for attempting to recover aborting interspecific or intraspecific hybrid embryos of Arachis on a relatively large scale.

\section{Literature Cited}

1. Baltensperger, D. D., G. M. Prine, and R. A. Dunn. 1986. Rootknot nematode resistance in Arachis glabrata. Peanut Sci. 13:7880.

2. Gardner, M. E. B., and H. T. Stalker. 1983. Cytology and leafspot resistance of section Arachis amphidiploids and their hybrids with Arachis hypogaea L. Crop Sci. 23:1069-1074.

3. Gregory, M. P., and W. C. Gregory. 1979. Exotic germplasm of Arachis L. interspecific hybrids. J. Hered. 70:185-193.

4. Halward, T. M., and H. T. Stalker. 1987. Comparison of embryo development in wild and cultivated Arachis species. Ann. Bot. 59:9-14.

5. Halward, T. M., and H. T. Stalker. 1987. Incompatibility mechanisms in interspecific peanut hybrids. Crop Sci. 27:456460.

6. Hull, F. H., and W. A. Carver. 1938. Peanut improvement. Fla. Agric. Exp. Sta. Ann. Rep., pp. 39-40.

7. Johansen, E. L., and B. W. Smith. 1956. Arachis hypogaea Arachis diogoi. Embryo and seed failure. Am. J. Bot. 43:250-258.

8. Johnson, B. B. 1981. Embryo-ovule culture. Env. Exp. Bot. 21 : 439. (Abstr.).

9. Mallikarjuna, N., and D. C. Sastri. 1985. In vitro culture of ovules and embryos from some incompatible interspecific crosses in the genus Arachis L. Proceedings International Workshop on Cytogenetics of Arachis. International Crops Research Institute for the Semi-Arid Tropics, Patancheru, P.O., India, pp. 153-163.

10. Mallikarjuna, N., and D. C. Sastri. 1985. Utilization of incompatible species in Arachis: Sequential hormone applications. Proceedings International Workshop on Cytogenetics of Arachis. International Crops Research Institute for the Semi-Arid Tropics, Patancheru, P.O., India, pp. 147-151.

11. Martin, J. P. 1970. Culture in vitro d'ovules d'arachide. Oleagineux 25:155-156.

12. Moss, J. P. 1980. Wild species in the improvement of groundnuts, pp. 525-535. in R. J. Summerfield and A. H. Bunting (eds.), Advances in Legume Science. Royal Botanic Gardens, Kew, England.

13. Moss, J. P. 1985. Breeding strategies for utilization of wild species of Arachis in groundnut improvement. Proceedings International Workshop on Cytogenetics of Arachis. International Crops Research Institute for the Semi-Arid Tropics, Patancheru, P.O., India, pp. 93-99.

14. Moss, J. P., H. T. Stalker, and H. E. Pattee. 1985. In vitro culture of A. hypogaea peg tips. Proceedings Amer. Peanut Res. Educ. Soc. 17:22 (Abstr.).

15. Moss, J. P., H. T. Stalker, and H. E. Pattee. 1988. Embryo rescue in wide crosses in Arachis. 1. Culture of ovules in peg tips of A. hypogaea. Ann. Bot. 61:1-7.

16. Murashige, T., and F. Skoog. 1962. A revised medium for rapid growth and bioassays with tobacco tissue cultures. Physiol. Plant. 15:473-497.

17. Pattee, H. E., H. T. Stalker, and J. P. Moss. 1988. Embryo rescue in wide crosses in Arachis. 2. Embryo development in cultured peg tips of A. hypogaea. Ann. Bot. 61:103-112.

18. Sastri, D. C., N. S. Nalini, and J. P. Moss. 1980. In vitro culture of Arachis ovaries and ovules, pp. 366-373. in P. S. Rao et al. (eds.), Proceedings Symposium on Plant Tissue Culture, Genetic Manipulation and Somatic Hybridization. Bhabha Atomic Research Center, Trombay, India.

19. Singh, A. K., D. C. Sastri, and J. P. Moss. 1980. Utilization of wild species at ICRISAT. Proceedings International Workshop on Groundnuts. International Crops Research Institute for the SemiArid Tropics, Patancheru, A.P., India, pp. 82-90. 
20. Smartt, J., and H. T. Stalker. 1982. Speciation and cytogenetics in Arachis, pp. 21-49. in H. E. Pattee and C. T. Young (eds.), Peanut Science and Technology. Amer. Peanut Res. Educ. Soc., Yoakum, TX.

21. Stalker, H. T. 1985. Cytotaxonomy of Arachis. Proceedings International Workshop on Cytogenetics of Arachis. International Crops Research Institute for the Semi-Arid Tropics, Patancheru, P.O., India, pp. 65-79.

22. Stalker, H. T., M. H. Seitz, and P. Reece. 1987. Effect of gibberellic acid on pegging and seed set of Arachis species. Peanut Sci. 14:21-25.
23. Ziv, M., and J. C. Sagar. 1984. The influence of light quality on peanut (Arachis hypogaea L.) gynophore pod and embryo development in vitro. Plant Sci. Lett. 34:211-218.

24. Ziv, M., and E. Zamski. 1975. Geotropic responses and pod development in gynophore explants of peanut (Arachis hypogaea L.) cultured in vitro. Ann. Bot. 39:579-583.

Accepted December 17, 1987 